\title{
A new fossil subfamily of Bethylidae (Hymenoptera) from the Early Cretaceous Lebanese amber and its phylogenetic position
}

\author{
Celso O. Azevedo ${ }^{1,3} \&$ Dany Azar ${ }^{2}$ \\ ${ }_{1}^{1}$ Departamento de Biologia, Universidade Federal do Espírito Santo. Avenida Marechal Campos 1468, Maruípe, \\ 29040-090 Vitória, ES, Brazil. E-mail: bethylidae@gmail.com \\ ${ }^{2}$ Department of Natural Sciences, Faculty of Sciences II, Lebanese University. Fanar - Matn, PO Box 26110217, Lebanon. \\ E-mail: azar@mnhn.fr \\ ${ }^{3}$ Corresponding author.
}

\begin{abstract}
A new subfamily, a new genus and a new species of Bethylidae are described and illustrated from a single individual in Early Cretaceous amber from central Lebanon. Lancepyrinae subfam. nov. represented by Lancepyris opertus gen. and sp. nov. present a mosaic of features common among several bethylid subfamilies. The new taxon is easily distinguished from related taxa mainly by the forewing venation, which has an unusual combination of closed lanceolate marginal cell, Rs+M tubular and well pigmented and M+RS angled. Phylogenetic analysis including indicates that Lancepyris opertus gen. and sp. nov. is a sister group of all subfamilies that have Coleoptera as hosts. A checklist of the 45 known fossil bethylid species is provided.
\end{abstract}

KEY WORDS. Lancepyris; Lower Cretaceous; Mesozoic; new genus; new species.

There are 44 fossil species reported for Bethylidae (see Appendix 1). Most of them were described by BRUES (1923, 1933, 1939) based on Baltic amber from the Lower Oligocene. Hitherto the geographic distribution of bethylid fossils is limited to a few sites around the world.

The oldest species of Bethylidae found up to date are recorded from the Lower Cretaceous, four species from Burmese amber described by Cockerell (1920) and two species from Taimyr amber described by Evans (1973).

While studying the Lebanese amber material provisionally deposited at the Muséum National d'Histoire Naturelle in Paris we found an amber piece containing an unusual bethylid specimen. Our first impression is that the specimen could represent a new subfamily, mainly due to the combination of characters it displays.

The main goals of this paper are 1) to describe a new taxon of Bethylidae, which is a good example illustrating the fossil biodiversity in Lebanon; 2) to ascertain its phylogenetic position among other bethylid subfamilies.

\section{MATERIAL AND METHODS}

The amber specimen containing the inclusion was cut (using a denticulate shaving blade), then polished using diatomite powder (or diatomaceous powder). After that, the specimen was prepared between two cover slips in a Canada balsam medium, as described by AzAR et al. (2003).
The specimen was examined with an Olympus SZX9 stereomicroscope and an Olympus CK40 inverted compound microscope. Drawings were made using a camera Lucida. Photographs were taken with an Olympus FE-5000 digital camera.

Measurements and indices used in this study are as follows: the length of the body was measured from the apex of the clypeus to the posterior margin of the last metasomal segment, excluding the male genitalia or the female sting. Length of the head (LH) was measured in frontal view from the vertex crest to the median apical margin of the clypeus. Width of the head $(\mathrm{WH})$ was measured in frontal view, with its maximum width including eyes. Width of the frons (WF) was measured in frontal view, where it is narrowest. Height of the eye (HE) was measured in lateral view across its maximum height (length). Ocello-ocular line (OOL) was measured in latero-dorsal view, taking the shortest distance from the eye top to the posterior ocellus. Width of the ocellar triangle (WOT) was measured in frontal view, taking its maximum width and including the ocelli. Diameter of the anterior ocellus (DAO) was measured in frontal view. The vertex-ocular line (VOL) was measured in dorsal view, taking the distance from the eye top to the vertex crest.

The nomenclature of the integument sculpture follows Harris (1979), of the wing venation follows Wharton et al. (1997), and the general nomenclature follows Evans (1964) and Azevedo (1999). 
The material used in this study was provided by insect collection of the following institutions: Universidade Federal do Espírito Santo, Brazil (UFES, curator M.T.Tavares), California Academy of Sciences, U.S.A. (CASC, R.Zuparko), Queen Sirikit Botanical Garden, Thailand (QSBG, W.Srisuka), Universidad de Panama, Panama (MUIP, D.Quintero).

We used a total of 15 taxa in order our cladistic analysis, three species from each of the major bethylid groups (Tab. I). We selected the scolebythid species Clystopsenella longiventris Kieffer, 1910 from Panama as outgroup because Scolebythidae are much closed to Bethylidae as point out by CARPENTER (1999).

Table I. Taxa analyzed of the ingroup.

\begin{tabular}{ll}
\hline \multicolumn{1}{c}{ Major group and species } & \multicolumn{1}{c}{ Locality } \\
\hline Bethylinae & \\
Lytopsenella testaceicornis (Kieffer, 1910) & Chile \\
Sierola leeuwinensis Turner, 1915 & Australia \\
Goniozus sp. & Brazil \\
Epyrini & \\
Epyris argentinicus Evans, 1969 & Brazil \\
Anisepyris analis (Cresson, 1872) & U.S.A. \\
Holepyris sp. & Madagascar \\
Mesitiinae & \\
Sulcomesitius sp. & Thailand \\
Metrionotus yarrowi Móczár, 1970 & U.A.E. \\
Heterocoelia sp. & Thailand \\
Pristocerinae & \\
Dissomphalus sp. & Madagascar \\
Pseudisobrachium graciliventri Ogloblin, 1925 & Brazil \\
Apenesia sp. & Madagascar \\
Sclerodermini & \\
Sclerodermus sp. & Madagascar \\
Nothepyris sulcatus (Azevedo, 1999) & Brazil \\
Cephalonomia sp. & Madagascar \\
\hline
\end{tabular}

The characters used in the analysis are those considered useful for distinguishing among subfamilies and tribes. They were taken from available keys such as those of Evans (1964), Terayama (2003b) and Azevedo et al. (2010). We also used some characters from recent cladistic analyses such as Sorg (1988), Terayama (2003a), Lanes \& Azevedo (2008). Additionally we included in the analysis a few characters never used before in the taxonomy of bethylid subfamilies and tribes.

The character matrix was constructed in DELTA (DALLwITZ et al. 1993, 1999). The characters were treated as unordered. The inapplicable and missing characters were coded as "?" in the matrix.

Tree search was heuristic. The resulting trees were rooted using the outgroup method. The consensus cladogram was ob- tained using the default options in TNT 1.1 (GoloвоғF et al. 2003), where all analyses were performed, tree swapping utilizing the TBR (Tree Bisection Reconnection method), implemented in the "new technology search" as a default, aided by Ratchet, with 10.000 iterations by each run. Following heuristic search with unweighted characters, Golloboff's implied weighting was applied with $K$ values 1-6. Character transformations were analysed and trees were manipulated graphically in Winclada version 1.00.08 by NIXON (1999). Character list is presented in Appendix 2.

\section{RESULTS}

\section{Taxonomy}

\section{Bethylidae Ashmead, 1893 Lancepyrinae subfam. nov.}

Type genus: Lancepyris gen. nov.

Diagnosis, female: Antenna with 13 segments; ocelli present; pronotal disc trapezoidal; posterior margin of pronotal disc evenly concave; scutellar groove present; metanotum long medially, but without median fovea; propodeal disc without spines on posterior corner; tegula present; fully winged; anterior margin of forewing straight; $\mathrm{C}$ vein of forewing present; $\mathrm{Rs}+\mathrm{M}$ of forewing tubular, well-pigmented, straight, and parallel to wing posterior margin; M+RS of forewing straight (Fig. 3); claws slightly arched; metasoma longer than mesosoma (Fig. 4); second metassomal tergite about as long as third. Male unknown.

\section{Lancepyris gen. nov.}

Type species: Lancepyris opertus sp. nov.

Diagnosis, female: Space between toruli depressed; forewing with marginal cell closed by tubular veins, lanceolate, with distal part of Rs vein almost straight; first discoidal cell rectangular; cu-a vein slightly arched; costal cell of forewing evenly narrow.

Etymology: Name refers to the shape of marginal cell of the forewing as lance tip.

\section{Lancepyris opertus sp. nov.}

Material: Holotype specimen AD-39, deposited in the Muséum National d'Histoire Naturelle, Paris.

Type locality and horizon. Early Cretaceous, Ain Dara, Caza Aley (Aley District), Mouhafazit Jabal Libnen (Governorate Mount Lebanon), Central Lebanon, collected by Dany Azar.

Diagnosis: As for the genus.

Description, female: Body length about $2.4 \mathrm{~mm}$, forewing length $1.6 \mathrm{~mm}$. Colour: Head and mesosoma black, metasoma dark castaneous; antenna, mandible and legs castaneous to dark castaneous; wings subhyaline; veins castaneous to dark castaneous.

Head (Figs 1-2): Mandible with at least three sharp apical teeth, short and thick, overlapping each other less than 50\% 


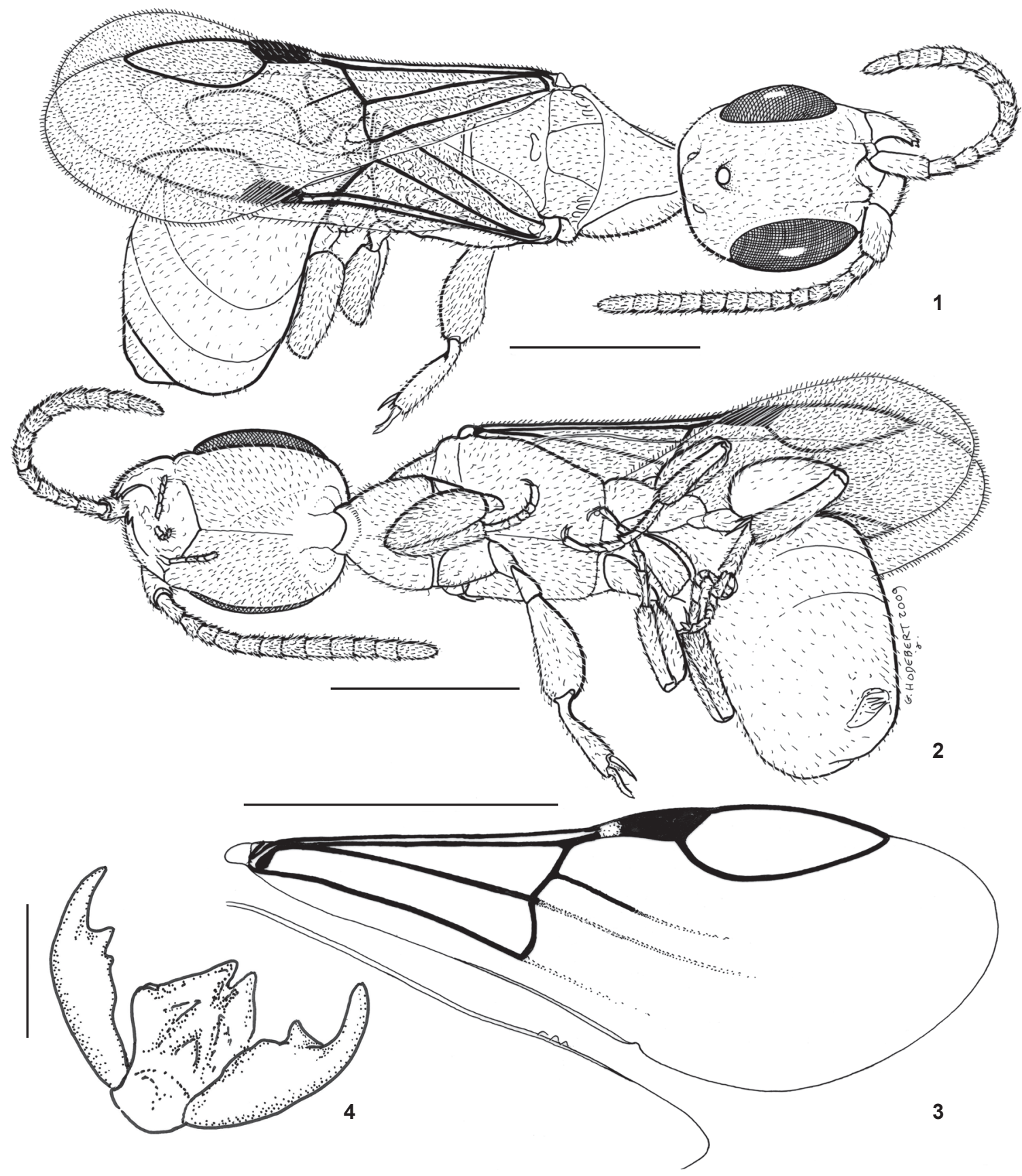

Figures 1-4. Lancepyris opertus sp. nov.: (1) Body, dorsal view; (2) body, ventral view; (3) wing; (4) claw, ventral view. Horizontal bars = $0.50 \mathrm{~mm}$, vertical bar $=0.03 \mathrm{~mm}$.

of their length; with basal callus. Clypeus short, median lobe very hardly visible as being hidden by antenna thus its shape cannot be determined, frons without median longitudinal carina; lateral lobe short and convex. Antenna filiform, with 13 segments, scape with ventral side arched, flattened in cross sec- tion, short, only about $2.2 \mathrm{x}$ as long as wide, pedicel longer than wide, flagellomeres I and XI distinctly longer than wide, flagellomeres II-X slightly longer than wide; pubescence short and subappressed with. Torulus slightly bulging, inter-torular distance more than torulus diameter, space between them de- 
pressed. Eye subelliptical, sparsely setose, mostly placed on lateral face of head. Frons with many small punctures. Head 1.08x as long as wide; width of frons $0.48 \mathrm{x}$ head width and $0.48 \mathrm{x}$ length of eye; ocello-ocular line $0.56 \mathrm{x}$ width of ocellar triangle; ocellar triangle with acute frontal angle, distance from vertex crest $0.55 \mathrm{x}$ diameter of anterior ocellus. Vertex straight in full dorsal view medially, corner broadly rounded. Temple profile diverging anteriorly in dorsal view. Vertex-ocular line $0.36 \mathrm{x}$ eye length. Gena as punctured as frons, completely separated from each other by median carina. Hypostomal carina mostly straight. Occipital and post-genal carinae absent. Palpal formula apparently 5:4 (number of segment not clearly visible), segments with cylindrical cross section, segments setose.

Mesosoma (Figs 1-2): Pronotal disc weakly coriaceous, punctures sparse and small, elongate, $2.2-2.3 \mathrm{x}$ as long as mesoscutum, trapezoidal, lateral margin strongly converging anterad, so that is narrow anteriorly, anterior margin with weak transverse carina, anterior third of disc with longitudinal median linear depression, median portion of posterior margin badly concave; pronotal declivity concave in profile. Notaulus narrow, complete, converging posterad. Parapsidal furrows present. Scutellum wide, posterior area unusually wide, posterior margin only slightly convex, scutellar groove touching mesoscutum, short, occupying just median third of scutellar basal width, wide, ends dilated, anterior margin straight, posterior margin arched medially, inner surface polished. Metanotum present medially, separating scutellum from propodeal disc. Propodeal disc with polished median triangular area, median carina absent, posterior transverse carina complete, lateral carina very complete and weak; spiracle elliptical, about $0.07 \mathrm{~mm}$ long, placed below lateral carina anteriorly; anterior transverse carina narrow, median carina absent, disc progressively narrowing posterad. Propleuron evenly convex in profile of ventral view. Prosternum small. Pleurosterna separated from each other by narrow groove.

Wings (Fig. 3): Forewing about 2.6x as long as its maximum width; dorsal face setose, anterior and apical margins fringed; with four closed cells (costal, median, submedian and marginal); costal cell elongate and longitudinally folded, not visible in full dorsal view; median cell subtriangular, submedian cells subrectangular, both with similar length and progressively wider apicad, veins $\mathrm{M}$ and RS forming a very weak obtuse angle between them, giving rise Rs+M vein nearly straight, almost parallel with $\mathrm{M}+\mathrm{Cu}$ vein, basal portion tubular and $1.4 \mathrm{x}$ as long as $\mathrm{M}+\mathrm{RS}$ vein together, apical portion spectral continuing beyond pterostigma; marginal cell lance-tip-shaped, progressively narrowing into acute tip apicad, Rs vein mostly straight, but arched basally; pterostigma elongate. Hind wing with three median hamuli equally distant one to another; $\mathrm{C}$ vein short; dorsal face setose, apical margin and most of posterior margin fringed, jugal lobe present but very hard to be observable accurately.

Legs: Coxae very shiny, especially forecoxa. Femora moderately dilated, metafemur slightly more dilated than fore fe- mur, which is about $2.3 \mathrm{x}$ as long as wide. Tibiae elongate; protibia with some distal spines and with one apical spur; mid tibia wide, with two spurs; hind tibia with two spurs. Tarsal formula 5:5:5; tarsomeres I and $\mathrm{V}$ of all tarsi longer than tarsomeres II-IV, all tarsomeres longer than wide, except protarsomere IV. Claws slightly curved, with three teeth progressively longer distad (Fig. 4).

Metasoma: Not petiolate. Tergites and sternites sparsely setose. Valvae III dilated, setose apically.

Etymology: Name refers to the marginal cell of the forewing to be closed.

\section{Phylogenetic analysis}

Examination of specimens resulted in the matrix shown in Table II. The many question marks for the three terminals taxa of Pristocerinae are due to the fact that, in those species, females are wingless. The search with equal weights resulted in three equally parsimonious trees. The strict consensus of this analysis resulted in one cladogram with 39 steps, consistency index (CI) of 0.79 and retention index (RI) of 0.89 (Fig. 5). The search with implied weights with $\mathrm{k}=1$ resulted in three equally parsimonious trees. The strict consensus of implied weight analyses resulted in one cladogram with 39 steps, CI $=0.79$ and $\mathrm{RI}=0.89$ (Fig. 6), which corresponds to exactly the same number of step and indices of the strict consensus with equal weighting.

The topology of the tree obtained under both equal and implied weights are very similar, the only difference is the internal relationship among the genera of Sclerodermini, in the former Sclerodermus retrieved as sister group of Nothepyris (Fig. 5), whereas in the latter Sclerodermus retrieved as sister group of Cephalonomia (Fig. 6). In the both analyses all major group of Bethylidae are retrieved as monophyletic, and Lancepyrinae as an independent clade as well.

All five major groups of Bethylidae were recovered as monophyletic groups, and in all analyses Lancepyris failed to cluster within them. Because of that we allocated it into a new subfamily, Lancepyrinae. Two synapomorphies support this clade, namely pronotal disc narrow anteriorly $(10,1)$ and poststigmal area of anterior margin of forewing slightly curved $(23,1)$. The latter gives the marginal cell a lanceolate aspect, and is the reason for the genus name.

\section{DISCUSSION}

The results of the phylogeny are surprising and confirm that the Lebanese fossil material has a mosaic of plesiomorphic and apomorphic features used to define subfamilies within Bethylidae. This makes the new species special. It is the $45^{\text {th }}$ described bethylid fossil species, and increases the known minimum age of Bethylidae from the Albian Cretaceous ( 105 million years ago) to the Barremian Cretaceous ( 125 million years ago). 
Table II. Data matrix of 31 characters used in the cladistic analyses.

\begin{tabular}{|c|c|c|c|c|c|c|c|c|c|c|c|c|c|c|c|c|c|c|c|c|c|c|c|c|c|c|c|c|c|c|c|}
\hline & & & & & & & & & & 1 & & & & & & & & & & 2 & & & & & & & & & & 3 & \\
\hline & 1 & 2 & 3 & 4 & 5 & 6 & 7 & 8 & 9 & 0 & 1 & 2 & 3 & 4 & 5 & 6 & 7 & 8 & 9 & 0 & 1 & 2 & 3 & 4 & 5 & 6 & 7 & 8 & 9 & 0 & 1 \\
\hline Clystopsenella & 0 & 0 & 0 & 0 & 0 & 0 & 0 & 0 & 0 & 0 & 0 & 0 & 0 & 0 & 0 & 0 & 0 & 0 & 0 & 0 & 0 & 0 & 0 & 0 & 0 & 0 & 0 & 0 & 0 & 0 & 0 \\
\hline Lancepyris & 0 & 1 & 0 & 0 & 0 & 1 & 0 & 0 & 0 & 1 & 1 & 1 & 0 & 0 & 1 & 0 & 1 & 0 & 0 & 0 & 0 & 0 & 1 & 0 & 0 & 1 & 0 & 0 & 1 & 0 & 0 \\
\hline Heterocoelia & 0 & 0 & 0 & 0 & 0 & 1 & 1 & 1 & 1 & 0 & 1 & 1 & 0 & 0 & 0 & 1 & 1 & 0 & 0 & 0 & 0 & 1 & 0 & 0 & 1 & 1 & 0 & 0 & 1 & 0 & 1 \\
\hline Sulcomesitius & 0 & 0 & 0 & 0 & 0 & 1 & 1 & 1 & 1 & 0 & 1 & 1 & 0 & 0 & 0 & 1 & 1 & 0 & 0 & 0 & 0 & 1 & 0 & 0 & 1 & 1 & 0 & 0 & 1 & 0 & 1 \\
\hline Metrionotus & 0 & 0 & 0 & 0 & 0 & 1 & 1 & 1 & 1 & 0 & 1 & 1 & 0 & 0 & 0 & 1 & 1 & 0 & 0 & 0 & 0 & 1 & 0 & 0 & 1 & 1 & 0 & 0 & 1 & 0 & 1 \\
\hline Psend & 0 & 0 & 1 & 1 & 1 & 1 & 0 & 1 & 1 & 0 & 1 & 1 & 0 & 1 & 1 & 0 & 1 & 0 & 1 & 1 & $?$ & $?$ & $?$ & $?$ & $?$ & $?$ & $?$ & $?$ & $?$ & 0 & 0 \\
\hline Apenesia & 0 & 0 & 1 & 1 & 1 & 1 & 0 & 1 & 1 & 0 & 1 & 1 & 0 & 1 & 1 & 0 & 1 & 0 & 1 & 1 & $?$ & $?$ & $?$ & $?$ & $?$ & $?$ & $?$ & $?$ & $?$ & 0 & 0 \\
\hline Disso & 0 & 0 & 1 & 1 & 1 & 1 & 0 & 1 & 1 & 0 & 1 & 1 & 0 & 1 & 1 & 0 & 1 & 0 & 1 & 1 & $?$ & $?$ & $?$ & $?$ & $?$ & $?$ & $?$ & $?$ & $?$ & 0 & 0 \\
\hline Lytops & 1 & 1 & 0 & 0 & 0 & 0 & 1 & 0 & 0 & 0 & 1 & 1 & 1 & 0 & 0 & 0 & 1 & 1 & 0 & 0 & 0 & 0 & 0 & 1 & 0 & 0 & 0 & 0 & 1 & 0 & 0 \\
\hline Sierola & 1 & 1 & 0 & 0 & 0 & 0 & 1 & 0 & 0 & 0 & 1 & 1 & 1 & 0 & 0 & 0 & 1 & 1 & 0 & 0 & 0 & 0 & 0 & 1 & 0 & 0 & 0 & 0 & 1 & 0 & 0 \\
\hline Goniozu & 1 & 1 & 0 & 0 & 0 & 0 & 1 & 0 & 0 & 0 & 1 & 1 & 1 & 0 & 0 & 0 & 1 & 1 & 0 & 0 & 0 & 1 & 0 & 1 & 0 & 0 & 0 & 0 & 1 & 0 & 0 \\
\hline Ani & 0 & 0 & 0 & 0 & 0 & 0 & 0 & 1 & 1 & 0 & 1 & 1 & 0 & 0 & 1 & 0 & 1 & 0 & 0 & 0 & 0 & 1 & 0 & 0 & 1 & 1 & 1 & 0 & 1 & 1 & 0 \\
\hline $\mathrm{Hol}$ & 0 & 0 & 0 & 0 & 0 & 1 & 0 & 1 & 1 & 0 & 1 & 1 & 0 & 0 & 1 & 0 & 1 & 0 & 0 & 0 & 0 & 1 & 0 & 0 & 1 & 1 & 1 & 0 & 1 & $\mid$ & 0 \\
\hline Epyris & $v$ & 0 & 0 & $v$ & 0 & 0 & 0 & 1 & 1 & 0 & 1 & 1 & 0 & 1 & 1 & $v$ & 1 & 0 & 0 & 0 & 0 & 1 & 0 & 0 & 1 & 1 & 1 & 0 & 1 & 1 & 0 \\
\hline Scler & 0 & 0 & 0 & 0 & 0 & 0 & 0 & 0 & 0 & 0 & 1 & 1 & 0 & 0 & 1 & 0 & 1 & 0 & 0 & 0 & 1 & 1 & 0 & 0 & 1 & 1 & 0 & 1 & 1 & 0 & 0 \\
\hline Nothe & 0 & 0 & 0 & 0 & 0 & 0 & 0 & 0 & 0 & 0 & 1 & 1 & 0 & 0 & 1 & 0 & 1 & 0 & 0 & 0 & 1 & 1 & 0 & 0 & 1 & 1 & 0 & 1 & 1 & 0 & 0 \\
\hline Cephalonomia & 0 & 0 & 0 & 0 & 0 & 0 & 0 & 0 & 0 & 0 & 1 & 1 & 0 & 0 & 1 & 0 & 1 & 0 & 0 & 0 & 1 & 1 & 0 & 0 & 1 & 1 & 0 & 1 & 1 & 0 & 0 \\
\hline
\end{tabular}
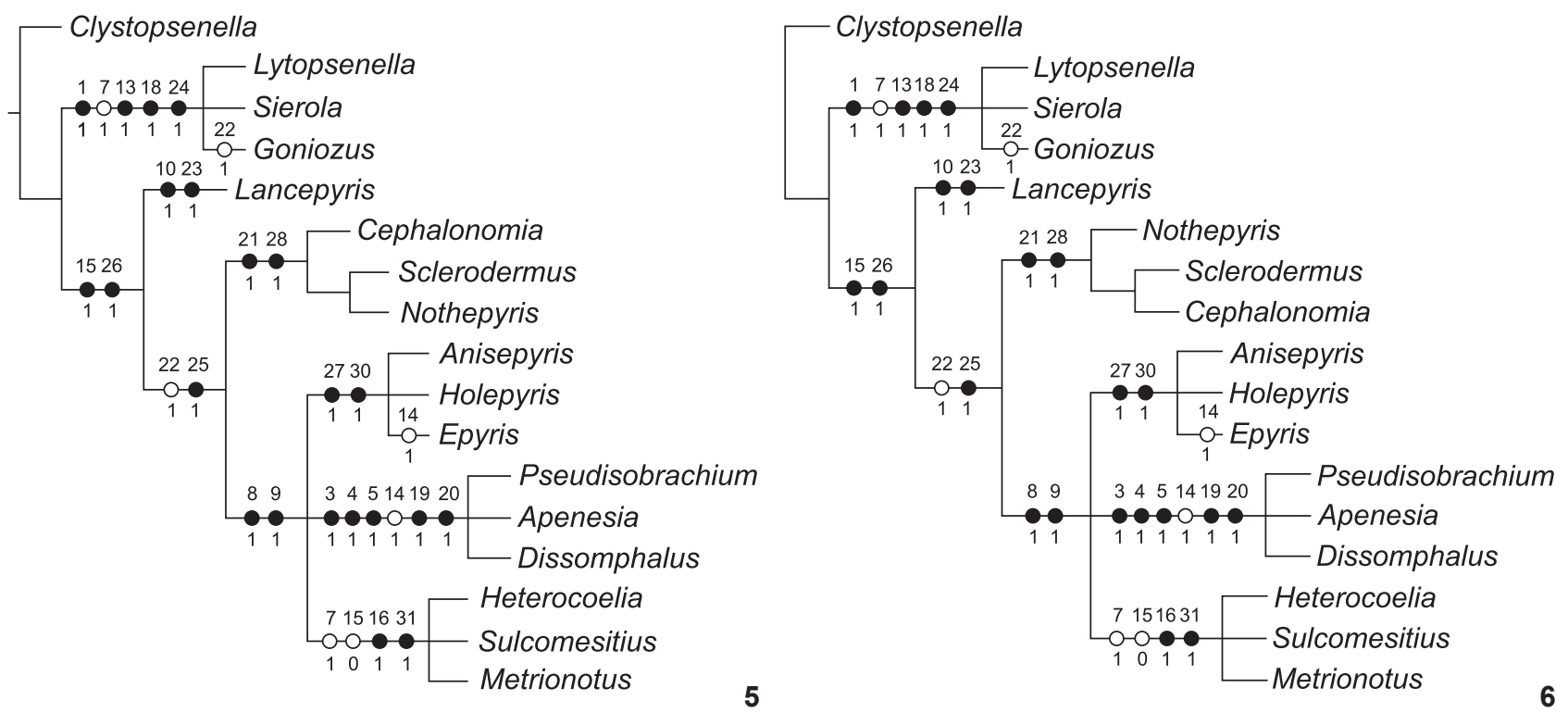

Figures 5-6. Strict consensus cladograms of three equally parsimonious trees of (5) equal and (6) implied weighting analyses.

Lancepyris has several characters found in Bethylinae, Pristocerinae and Epyrinae. However our results indicate that it constitutes an independent clade. Consequently we allocated it into a new subfamily.

The mandibles of Lancepyris opertus are short and thick as in Bethylinae. Figure 14 in AzEvEDo (2008b) illustrates these con- ditions. Representatives of Pristocerinae and Epyrini have more elongate mandibles. The clypeus of the new species does not extend backward into the frons, which makes it different from all species of Bethylinae. This character does not correspond to character 4 "presence of an unsculpture streak frontally" of Polaszek \& KROMBeIN (1994) (= streak which extends backward 
from proximal end of clypeus carina). This streak can be present or absent in Bethylinae, but the clypeal carina always extends backwards. The antennae have the scape short like in Bethylinae (see fig. 4 in AzEvedo 2008b). The inter-torular space is depressed, which is not Bethylinae-like. The eyes are unusually large as in the Epyrinae genera Formosiepyris Terayama and Disepyris Kieffer [see figs 6 and 12 in Terayama (2004) respectively].

The pronotal disc of Lancepyris opertus is elongate and trapezoidal; this resembles the male of the pristocerine genus Pseudisobrachium as in figures 63 and 80 in AzEvedo (2008a). The median portion of the posterior margin of the pronotal disc is evenly, slightly concave, and the typical convexity found in Bethylinae is therefore absent. There is a median fovea at the metanotum, which separates the scutellum from the propodeal disc. That does not resemble the condition found in Epyrinae, but is similar to states found in other subfamilies. The propodeal disc is well marked with posterior and lateral carinae. The propodeal faces (disc, lateral and declivity) are angled one to another. This gives it a cubical aspect, not similar to the condition found in Pristocerinae, but resembling the one found in other subfamilies.

The forewing venation of Lancepyris opertus is very unusual. Two features deserve special attention. First, the Rs+M is tubular and well pigmented. The presence of this vein is a main diagnostic character for Bethylinae. However, in Lancepyris, this vein is straight and almost parallel with the $\mathrm{M}+\mathrm{Cu}$, similar to what happens in Epyrinae and other groups in which the vein is spectral or not well pigmented. In Bethylinae, by contrast, this vein is curved posterad. Furthermore, the M+RS in angulate medially in Bethylinae, differing from the condition found in all other groups that have the M+RS straight, not forming any angle where the Rs+M originates. Second, the Rs vein is almost straight, reaching the R1 vein. Because of that, the marginal cell is closed and is lanceolate in shape.

In the claws we find another important character for Lancepyris opertus. The claws in Bethylinae are strongly angled basally. This represents one of the synapomorphies of the group. In Lancepyris the claws are only slightly curved as in the other bethylid groups.

Another point that deserves attention is the cladistic position of Lancepyrinae. As CARR et al. (2010) have properly shown, Bethylinae are the sister group to the other bethylid subfamilies. This suggests two separate and roughly equivalent radiations of bethylid wasps: in the first group Lepidoptera are used as hosts, whereas in the other Epyrinae (Epyrini + Sclerodermini), Mesitinae and Pristocerinae Coleoptera are favored. Lancepyrinae are a sister group to all subfamilies that have Coleoptera as hosts. In our analyses we have obtained this same topology, and Lancepyrinae were retrieved as sister group of coleopterophagous clade.

The discovery of Lancepyris opertus highlights the strange forms of Bethylidae that existed during the Early Cretaceous, when the global modern continental ecosystems originated.
The study of fossils from this peculiar period is a key to understanding the evolutionary scenario that took place back then. Once again the Lebanese amber demonstrates that the evolutionary history of the Barremian Cretaceous is much more complicated than one can conclude by studying the extant representatives alone. Fossil sampling is always a minute fraction of the actual biodiversity of the past, and hopefully more field researches will find more representatives of the past biodiversity.

Among all the ambers, the Lebanese one is probably the most important for several reasons: it is the oldest amber containing intensive biotic inclusions (Azar 1997a, b, Azar \& NeL 1998, POINAR 1992); it is contemporary with the appearance of flowering plants and all the ecosystem modifications that resulted; it is a witness of the beginning of the diversification of modern entomofauna and the vanishing of some old groups of insects. Amber in Lebanon is found in lens of dark clay or shale associated with lignite and plant debris, sometimes in purely fluvial deposition systems, i.e. in channels, or riversides, and sometimes the deposition is subject to marine influences, i.e. in a deltaic zone, or on the littoral (in the intertidal area) (AZAR 2007).

\section{ACKNOWLEDGMENTS}

We are grateful to Diego N. Barbosa who helped us to run the data in DELTA, TNT and Winclada, to André Nel for allowing us to use his laboratory at the Museum National de l'Histoire Naturelle where this study was partially carried out; to Isabel Alencar who suggested some characters for the matrix; to CNPq grants \#303216/2004-2, \#306231/2007-7 and \#502656/2007-7 for the fellowships provided to first author, to CNPq grant \#563953/05-5 and FAPES grants \#39353842/07 and \#41106407/08 for the financial support. This paper is a contribution to the team project "Biodiversity: origin, structure, evolution and geology" awarded to D. Azar by the Lebanese University.

\section{LITERATURE CITED}

AzAR, D. 1997a. A new method for extracting vegetal and insect fossils from the Lebanese amber. Palaeontology 40: 1027-1029. AzAR, D. 1997b. Lebanese Amber. Meganeura 1: 26-27.

AzAR, D. 2007. Preservation and accumulation of biological inclusions in Lebanese amber and their significance. Comptes rendus - Palevolution 6: 151-156.

AzAR, D. \& A.Nel. 1998. Lebanese Lower Cretaceous amber. Meganeura 2: 18-20.

Azar, D.; V. Perrichot; D. Néraudeau \& A. Nel. 2003. New psychodid flies from the Cretaceous ambers of Lebanon and France, with a discussion about Eophlebotomus connectens Cockerell, 1920 (Diptera, Psychodidae). Annals of the American Society of America 96: 117-127. 
Azevedo, C.O. 1999. Revision of the Neotropical Dissomphalus Ashmead, 1893 (Hymenoptera, Bethylidae) with median tergal processes. Arquivos de Zoologia 35: 301-394.

Azevedo, C.O. 2008a. Characterization of the types of the Neotropical Pseudisobrachium (Hymenoptera, Bethylidae), with a key to species. Revista Brasileira de Zoologia 25: 737-801.

Azevedo, C.O. 2008b. Synopsis of Prosierola (Hymenoptera, Bethylidae). Zootaxa 1912: 45-58.

Azevedo, C.O.; I.D.C.C. Alencar \& D.N. Barbosa. 2010. Order Hymenoptera, family Bethylidae, p. 388-411, In: A. van HARTEN (Ed.). Arthropod Fauna of UAE. Abu Dhabi, Dar Al Ummah Printing, Publishing, Distribution \& Advertising, vol. 3, 700p.

Brues, C.T. 1923. Some new fossil parasitic Hymenoptera from Baltic amber. Proceedings of the American Academy of Arts and Sciences 58: 327-346.

BRues, C.T. 1933. The parasitic Hymenoptera of the Baltic Amber. Part I. Bernstein-Forschungen 3: 4-172.

Brues, C.T. 1939. New Oligocene Braconidae and Bethylidae from Baltic Amber. Annals of the Entomological Society of America 32: 251-263.

Carpenter, J.M. 1999. What do we know about chrysidoid (Hymenoptera) relationships? Zoologica Scripta 28: 215-231.

Carr, M.; J. Peter; W. Young \& P.J. Mayhew. 2010. Phylogeny of bethylid wasps (Hymenoptera: Bethylidae) inferred from 28S and $16 \mathrm{~S}$ rRNA genes. Insect Systematics \& Evolution 41: 55-73.

CoCKerell, T.D.A. 1920. XXXVI. Fossil arthropods in the British Museum. I. Annals Magazine of the Natural History of London, series 9, 5: 273-279.

Dallwitz, M.J.; T.A. Paine \& E.J. Zurcher. 1993. 'User's Guide to the DELTA System: a General System for Processing Taxonomic Descriptions. Available online at: http:// biodiversity.uno.edu/delta [Accessed: May 10 $0^{\text {th }}, 2010$ ]

Dallwitz, M.J.; T.A. Paine \& E.J. Zurcher. 1999. User's Guide to the DELTA Editor. Available online at: http://biodiversity.uno.edu/ delta [Accessed: May 10 $0^{\text {th }}, 2010$ ]

Evans, H.E. 1964. A synopsis of the American Bethylidae (Hymenoptera, Aculeata). Bulletin of the Museum of Comparative Zoology 132: 1-222.

Evans, H.E. 1973. Cretaceous Aculeata wasps from Taimyr, Siberia (Hymenoptera). Psyche 80: 166-178.
Goloboff, P.; J. Farris \& K. Nixon. 2003. T.N.T.: Tree Analysis Using New Technology. Program and documentation. Available online at: http://www.zmuc.dk/public/phylogeny [Accessed: May 10 ${ }^{\text {th }}, 2010$ ]

HARRIS, R.A. 1979. A glossary of surface sculpturing. Occasional Papers in Entomology 28: 1-31.

Lanes, G.O. \& C.O. Azevedo. 2008. Phylogeny and Taxonomy of Sclerodermini (Hymenoptera, Bethylidae, Epyrinae). Insect Systematics \& Evolution 39: 55-86.

NIXON, K.C. 1999. Winclada (BETA) ver. 0.9.9. New York, Published by the author.

Poinar, G.O. 1992. Life in amber. Standford, Standford University Press, 350p.

Polaszer, A. \& K.V. Krombein. 1994. The genera of Bethylinae (Hymenoptera, Bethylidae). Journal of Hymenoptera Research 3: 91-105.

Sorg, M. 1988. Zur Phylogenie und Systematik der Bethylidae (Insecta: Hymenoptera, Chrysidoidea). Sonderveröffentlichungen des Geologisches Institut der Universität zu Köln 63: 1-146.

Terayama, M. 2003a. Phylogeny Systematics of the family Bethylidae (Insecta: Hymenoptera) Part I. Higher classification. The Academic Reports of the Faculty of Engineering Tokyo Polytechnic University 26: 1-15.

Terayama, M. 2003b. Phylogeny Systematics of the family Bethylidae (Insecta: Hymenoptera) Part II. Keys to subfamilies, tribes and genera in the world. The Academic Reports of the Faculty of Engineering Tokyo Polytechnic University 26: 16-29.

Terayama, M. 2004. Formosiepyris, a new genus of the family Bethylidae (Hymenoptera, Chrysidoidea) from the Oriental region, with a proposal of a new synonymy of genus. Liberal Arts 12: 91-99.

Wharton, R.A.; P.M. Marsh \& M.J. Sharkey. 1997. Manual of the New World genera of the family Braconidae (Hymenoptera). Special Publication of the International Society of Hymenopterists 1: 1-439.

Submitted: 04.V.2011; Accepted: 12.III.2012.

Editorial responsibility: Walter A.P. Boeger

Appendix 1. Checklist of fossil Bethylidae species (period and type locality in brackets).

\section{Bethylinae}

Goniozus contractus (Brues, 1933) [Oligocene, Baltic amber] Goniozus respectus Sorg, 1988 [Miocene, Dominican amber] Lytopsenella crastina (Brues, 1923) [Oligocene, Baltic amber] Lytopsenella kerneggeri Ohl, 1995 [Upper Eocene, Baltic amber] Lytopsenella setigera (Brues, 1923) [Oligocene, Baltic amber] Lytopsenella simplex (Brues, 1923) [Oligocene, Baltic amber] Prosierola submersa Brues, 1933 [Lower Oligocene, Baltic amber] Protobethylus eocenicus De Ploeg \& Nel, 2004 [Lowermost Eocene, Oise French amber] Sierola hastata Sorg, 1988 [Upper Eocene, Baltic amber] 


\section{Epyrini}

Anisepyris gradates Sorg, 1988 [Miocene, Dominican amber]

Elektroepyris magnificus Perrichot \& Nel, 2008 [Eocene, French amber (Oise)]

Epyris atavellus Cockerell, 1920 [Cretaceous, Burmese amber]

Epyris bifossatus (Brues, 1939) [Lower Oligocene, Baltic amber]

Epyris deletus Brues, 1910 [Miocene, U.S.A. (Texas)]

Epyris inhabilis Brues, 1923 [Oligocene, Baltic amber]

Epyris longiceps (Brues, 1923) [Oligocene, Baltic amber]

Epyris ramosus Meunier, 1906 [Pleistocene, Tanzania]

Epyris rectinervis (Cockerell, 1921) [Oligocene, England]

Epyris tenellus Statz, 1938 [Oligocene, Germany (Siebengebirges)]

Holepyris dubius Brues, 1933 [Lower Oligocene, Baltic amber]

Holepyris minor (Brues, 1939) [Lower Oligocene, Baltic amber]

Holepyris planiceps Brues, 1933 [Lower Oligocene, Baltic amber]

Holepyris precursor Brues, 1933 [Lower Oligocene, Baltic amber]

Holepyris robustus (Brues, 1933) [Lower Oligocene, Baltic amber]

Isobrachium concaptum Brues, 1933 [Lower Oligocene, Baltic amber]

Isobrachium invelatum Brues, 1933 [Lower Oligocene, Baltic amber]

Laelius nudipennis Brues, 1933 [Lower Oligocene, Baltic amber]

Laelius pallidus Brues, 1933 [Lower Oligocene, Baltic amber]

Plastanoxus atrescens Sorg, 1988 [Eocene, Baltic amber]

Rhabdepyris elatus Brues, 1933 [Lower Oligocene, Baltic amber]

Rhabdepyris gallicus Perrichot \& Nel, 2008 [Eocene, Oise French amber (Oise)]

Rhabdepyris setosus Brues, 1933 [Lower Oligocene, Baltic amber]

Lancepyrinae subfam. nov.

Lancepyris opertus Azevedo \& Azar gen. \& sp. nov. [Early Cretaceous, Lebanese amber]

\section{Pristocerinae}

Apenesia electriphila Cockerell, 1917 [Cretaceous, Burmese amber]

Parapristocera skwarrae Brues, 1933 [Lower Oligocene, Baltic amber]

Pseudisobrachium oligocenicum Theobald, 1937 [Oligocene, France (Cereste)]

Archaeopristocera miki Terayama, 2004 [Miocene, Dominican amber]

\section{Sclerodermini}

Celonophamia taimyria Evans, 1973 [Upper Cretaceous, Russia (Taimyr)]

Plastanoxus atrescens Sorg, 1988 [Upper Eocene, Baltic amber]

Sclerodermus quadridentatus Cockerell, 1917 [Cretaceous, Burmese amber]

\section{Incerta sedis}

Archaepyris minutus Evans, 1973 [Upper Cretaceous, Russia (Taimyr)]

Bethylitella cylindrella Cockerell, 1917 [Cretaceous, Burmese amber]

Bethylopteron ambiguum Brues, 1933 [Lower Oligocene, Baltic amber]

Messoria copalina Meunier, 1916 [subfossil from Copal resin, Madagascar]

Protopristocera sucini Brues, 1923 [Lower Oligocene, Baltic amber]

Appendix 2. Character list.

1. Clypeal intrafrontal extension: (0) absent; (1) present.

2. Scape length: (0) long (more than $2 x$ longer than pedicel); (1) short (less than $2 x$ longer than pedicel).

3. Pedicel length: $(0)$ longer than wider; $(1)$ shorter than wide.

4. Eye size: (0) large (HE more than $0.25 \times \mathrm{LH}$ ); (1) reduced (HE less than $0.25 \times \mathrm{LH}$ ).

5. Present of ocelli: (0) present; (1) absent.

6. Antennal socket size: (0) reduced (less than $0.5 x$ as long as wide); ( 1 ) projected (more than $0.5 x$ as long as wide).

7. Flatness of inter-torular space: (0) depressed; (1) bulging. 
8. Presence of occipital carina: (0) absent; (1) present.

9. Presence of post-genal carina: (0) absent; (1) present.

10. Pronotal disc shape: (0) wide anteriorly; (1) narrow anteriorly.

11. Pronotal disc length: (0) short (shorter than mesoscutum); (1) long (shorter than mesoscutum).

12. Prosternum size: (0) large (when larger than forecoxa); (1) small (smaller than forecoxa).

13. Posterior margin of pronotal disc: (0) evenly concave; (1) convex medially.

14. Scutellar groove: (0) present; (1) absent.

15. Metanotum: (0) with median fovea; (1) without median fovea.

16. Propodeal disc, spine of posterior corner: (0) absent; (1) present.

17. Position of foretrochanter insertion: (0) medially at coxa; (1) apically at coxa.

18. Claw shape: (0) curved; (1) angled.

19. Presence of tegulae: (0) present; (1) absent.

20. Presence of wings: (0) present; (1) absent.

21. Shape of anterior margin of forewing: (0) straight; (1) concave.

22. Openness of marginal cell of forewing: (0) closed (completely surrounded by tubular veins); (1) opened (not completely surrounded by tubular veins).

23. Profile of post-stigmal area of anterior margin of forewing: (0) straight; (1) slightly curved.

24. First discoidal cell shape: (0) rectangular; (1) pentagonal.

25. Conspicuousness of Rs+M: (0) tubular; (1) spectral.

26. $M+R S$ vein shape: (0) angled; (1) almost straight.

27. cu-a vein shape: (0) slightly arched; (1) arched posteriorly.

28. Presence of costal vein: (0) present; (1) absent.

29. Costal cell width: (0) wide (wider than stigma); (1) narrow (narrower than stigma).

30. Metasomal petiolar root differentiation: (0) absent; (1) present.

31. Size of second metasomal tergite: (0) regular sized; (1) much larger than other tergites.

ZOOLOGIA 29 (3): 210-218, June, 2012 